\title{
Effect of Differential Levels of Fertilizer and Row Spacing of Brown Top Millet [Brachiaria ramosa (L.)] on Soil Physicochemical Properties of Entisol of Bastar Plateau Zone of Chhattisgarh
}

\author{
Danish Ahmed Siddiqui, G.K. Sharma ${ }^{*}$, T. Chandrakar, A. K. Thakur, and A. Pradhan
}

\author{
Shaheed Gundadhur College of Agriculture and Research Station, \\ Kumhrawand, Jagdalpur-494005, Chhattisgarh (India)
}

*Corresponding author

\section{Keywords \\ Brown Top Millet, Row spacing, Fertilizer doses, \\ Entisols, Soil properties}

\section{Article Info}

Accepted: 10 August 2020 Available Online: 10 September 2020

\section{A B S T R A C T}

A field study was conducted at S.G. College of Agriculture and Research Station, Jagdalpur (Chhattisgarh). The experiment was laid out in a split plot design with 3 levels of fertilizer as main plot and 4 levels of row spacing as sub plot with 3 replications. Results showed that the effect of levels of fertilizer on soil properties, the highest values of available $\mathrm{N}\left(255 \mathrm{~kg} \mathrm{ha}^{-1}\right), \mathrm{P}\left(10.8 \mathrm{~kg} \mathrm{ha}^{-1}\right)$ and $\mathrm{Fe}(35.8 \mathrm{ppm})$ in soil were recorded with $125 \%$ of RDF and these parameters increased significantly with the increase in levels of fertilizer from 75 to 100 and 100 to $125 \%$ of RDF. The increase in available N and P with increased levels of fertilizer for these nutrients were obvious but increase in available $\mathrm{Fe}$ with increasing fertilizer doses of only NP fertilizer might be either due to the acidifying effect during the nitrification of urea or through replacement of $\mathrm{Fe}^{2+}$ from exchangeable site on clay by the $\mathrm{NH}_{4}{ }^{+}$ion formed after its hydrolysis of urea. Whereas in case of effect of row spacing on soil properties, the highest values of available $\mathrm{N}\left(233 \mathrm{~kg} \mathrm{ha}^{-1}\right), \mathrm{P}$ $\left(9.3 \mathrm{~kg} \mathrm{ha}^{-1}\right)$ and $\mathrm{K}\left(198 \mathrm{~kg} \mathrm{ha}^{-1}\right)$ in soil were recorded under $60 \mathrm{~cm}$ row spacing. The available $\mathrm{N}$ in soil increased significantly with increasing the row spacing from 22.5 to 45 $\mathrm{cm}, 30$ to $60 \mathrm{~cm}$ and 45 to $60 \mathrm{~cm}$,but the values are at par with each other when the row spacing increased from 22.5 to $30 \mathrm{~cm}, 30$ to $45 \mathrm{~cm}$. The available $P$ in soil increased significantly with increasing row spacing from 22.5 to $30 \mathrm{~cm}$ and 30 to $60 \mathrm{~cm}$ but the values are at par with each other when the row spacing increased from 30 to 45 and 45 to $60 \mathrm{~cm}$. The available $\mathrm{K}$ in soil increased significantly with increasing row spacing from 22.5 to $45 \mathrm{~cm}$, however the values are at par with each other when row spacing increased from 22.5 to 30,30 to 45 and 45 to $60 \mathrm{~cm}$. The increase in available N P and K with increased row spacing was found might be due to their less utilization in wider spacing having lower plant population in comparison to narrow row spacing. The crop with narrow spacing had greater plant population that could be able to utilize more available nutrients in the soil. The other soil parameters under study were found non significant with the levels of fertilizer and row spacing.

\section{Introduction}

Browntop millet (Brachiaria ramosa L.) belongs to the family Poaceae (Grass family) and is called with different names at different places like locally called as pedda-sama and korne, Korale in Kannada and Andakorra in 
Telugu (Fuller, 2014). Recently this crop is gaining popularity in several dry parts of India in terms of cultivation and consumption. In India, though the crop gaining lots of importance because of its nutritional value; its cultivation and the distribution is very low and is restricted to Andra Pradesh, Karnataka, and Tamil Nadu states of South India (Kimata et al., 2000). The brown top millets are also rich in many nutrients and are very delicious. The millet is free from gluten and rich in essential nutrients. Also, it's rich in fiber $(12.5 \%)$ compared to other crops. Lower incidence of cardiovascular diseases, duodenal ulcer, and hyperglycemia (diabetes), reported among those who regularly consume millets.

Nutrient supply in soil is one of the most important factors that determine the growth of the crop. Fertilizer is the major source of plant nutrients required in sufficient quantity to maintain the nutrient supply in the soil. The response of crop to fertilizers varies widely from place to place, depending upon the native fertility level of soil, environmental condition and genotype. A crop would express its full potential only when it is backed up by good agronomic practices. Optimum plant density provides conditions for proper light interception throughout the crop growth period. Further, it is important to realize that plant density should be defined not only in terms of number of plants per unit area but also in terms of arrangement of these plants on the ground (planting geometry/spatial arrangement) as it helps in efficient harvesting of solar energy with least competition for growth factors viz., water and nutrient uptake which ultimately decides the expression of phenotypic and genotypic character of the crop.

Chhattisgarh has four different soil types i.e. Entisols, Inceptisols, Alfisols, and Vertisols mainly developed by the action and interaction of relief, parent material, and climatic factors. Entisols cover $19.5 \%$ cultivated area of the state, most of the Bastar plateau contains these soils are known for absence or near absence of horizons that reflects the soil formation process. Though, the Entisols aren't thought well for the production of many crops, millets can be grown successfully. The soil is very hard and harsh which leads to limited root and shoot growth. With proper water supply and fertilization, these soils can be used in agriculture (USDA-NRCS, 2006).

Intensive land use with continuous use of higher doses of inorganic fertilizers significantly influences soil health. This has raised concerns about the potential long term adverse effects on soil health and environmental quality (Sarkar and Singh 1997). Marked deterioration in soil physicochemical properties resulting from continuous application of nitrogen $(\mathrm{N})$, phosphorus $(\mathrm{P})$, and potassium $(\mathrm{K})$ fertilizers was reported (Parameswar et al., 1989). Many attempts have been made to utilize the land for the millets still the information on effect of nutrient doses and row spacing are lacking. Henceforth, an attempt has been made to undertake this study with the objective to know the effect of level of fertilizer and row spacing of brown top millet on soil physicochemical properties.

\section{Materials and Methods}

\section{Location and physiographic setting}

The experiment was carried out during Kharif 2019 at Upland Research cum Instructional Farm, Shaheed Gundadhur College of Agriculture and Research Station, Lamker, Jagdalpur, Bastar (Chhattisgarh). Bastar plateau agro-climatic zone lies between the latitude ranging from 17044' to 20030' North and longitude from 82015 ' to 82020' East 
and, physiographically, is a part of Dandyakaranya upland, which is characterized by undulating topography with well marked elevations and depression with complex and heterogeneous setting (Ratre, 2014).

\section{Climate and weather conditions}

The climate of the zone is hot and sub humid with hot summer and cool winter. The zone receives an annual rainfall of 1300 to 1600 $\mathrm{mm}$ mostly in the month of July and August. The zone is flats in some parts while most of it undulating with slopes of varying magnitude (Ratre, 2014).

\section{Soil type}

In Bastar, the land is undulating and hence the soils vary considerably from top of the hillock to the valley. The soil types in Bastar district vary from Marhan (Entisols) to Gabhar (Vertisols). Gabhar is the valley portion of the undulating terrain. Tikra (Inceptisols) and Mal (Alfisols) lies in between these two (Ratre, 2014). Most of the Bastar plateau contains these Entisols. Though, the Entisols aren't good for the production of many crops, millets were grown better. It may form in a variety of climatic conditions. The soil is very hard and harsh which leads to limited root and shoot growth. With proper water supply and fertilization, these soils can be used in agriculture (USDA-NRCS, 2006).

\section{Cropping history of the experimental field}

Sometimes, the experimental results may get affected by the previous crop grown and the experiment carried out over there in that particular area. Henceforth, knowing the cropping history may help in solving many technical errors. The crops being taken during last 3 years were maize during kharif season of 2016 and 2017 and brown top millet during kharif season of 2018.

\section{Experimental details}

The field experiment was framed with a total of 12 treatment combination of the application of 3 differential levels of fertilizer with 4 differential levels of row spacing of brown top millet (variety wild) in a split plot design with 3 replications and its impact on crop yield was assessed after harvesting of crop. The fertilizer levels were composed of 75,100 and $125 \%$ of recommended dose of fertilizer (RDF) which was 40:20:00 kg nitrogen: phosphorous: potassium $\mathrm{ha}^{-1}$. The row spacing of brown top millet tested under study was $22.5,30,45$ and $60 \mathrm{~cm}$. In the present experiment two split doses of nitrogen was applied, initial dose of $50 \%$ was applied during the time of sowing and the rest was applied 15 days after sowing.

\section{Crop management}

The plot was ploughed well using tractor drawn disc plough; cultivator was used to break the clods and to loosen the soil before taking the experiment. The layouts were made concerning different treatments and replications. The seeds which were locally available were hand sown in the experimental plot on 27 July 2019. Weeds may be the major obstacles in the present experiment. Henceforth, three hand weeding was carried out to suppress there activity. The plant protection measures were taken as per the need of the crop. Once when the fingers were matured the crop was harvested manually.

\section{Observations recorded}

Soil samples before and after harvest of crop were collected and analyzed for estimation of $\mathrm{pH}, \mathrm{EC}, \mathrm{OC}$ and available $\mathrm{N}, \mathrm{P}, \mathrm{K}, \mathrm{Mn}, \mathrm{Zn}$, $\mathrm{Fe}$ and $\mathrm{Cu}$ using standard procedures. The data of analysis of initial soil samples are presented in table 1. The $\mathrm{pH}$ was recorded using $\mathrm{pH}$ meter. The electrical conductivity of 
soil was estimated using EC meter. The organic $\mathrm{C}$ in soil was estimated using Walkley and Black titration method (1934). The $\mathrm{N}$ was determined by alkaline potassium permanganate method of Subbiah and Asija, 1956. Soil available phosphorus was extracted by $\mathrm{NaHCO} 3(\mathrm{pH} 8.5)$ as described by Olsen et al., (1954) and $\mathrm{P}$ in extract was determined by ascorbic acid method using spectrophotometer (Watnabe and Olsen 1965). The soil potassium was extracted by neutral normal ammonium acetate and determined with the help of flame photometer as described by Muhr et al., (1965). The available micronutrients $\mathrm{Zn}, \mathrm{Cu}, \mathrm{Fe}$ and $\mathrm{Mn}$ were extracted by using $0.005 \mathrm{M}$ diethylene triamine penta acetic acid, $0.01 \mathrm{M}$ calcium chloride dehydrate and $0.1 \mathrm{M}$ amine buffered at pH 7.3 (Lindsay and Norvell, 1978) and content were analyzed using atomic absorption spectrophotometer (AAS).

\section{Results and Discussion}

The variations in the soil parameters due to levels of fertilizer and row spacing are presented in table 2 and figure 1-10 and the results are interpreted and discussed with the supportive reasons here under following heads.

\section{pH}

The data clearly reveals that the fertilizer levels, applied to brown top millet in an Entisol, had no significant effect on soil $\mathrm{pH}$. Several workers have reported that the application of fertilizers at different levels had no significant impact on soil reaction (Deekshitha et al., 2017 and Jamal et al., 2010). The no effect of fertilizer levels on soil $\mathrm{pH}$ may be due to high buffering capacity of soils (Kumar and Tarafdar, 2011).

The mean soil $\mathrm{pH}$ values ranged narrowly between 5.5 and 5.6 under different fertilizer levels. Similarly, Wany (2012) reported the soil $\mathrm{pH}$ ranging from 4.3-5.5 in Entisols. Jena et al., (2008) also reported the soil pH in the range of 4.6 to 7.5, in a study with an Entisol in deltanic alluvium of coastal Orissa. The data clearly showed that row spacing of brown top millet, in an Entisol at Bastar plateau region of Chhatisgarh, had no significant effect on soil $\mathrm{pH}$. No significant combined effect of fertilizer doses and row spacing on soil $\mathrm{pH}$ of brown top millet was recorded in this study.

\section{Electrical Conductivity (EC)}

The data on soil electrical conductivity didn't differ significantly with the variation in fertilizer levels, however, it trends increasing with increase in fertilizer doses. Similar findings were reported by Deekshitha et al., (2017). The mean values of soil electrical conductivity due to fertilizer levels were ranging between 0.07 to $0.09 \mathrm{dS} \mathrm{m}^{-1}$.

The data clearly showed that row spacing of brown top millet had no significant effect on soil electrical conductivity in an Entisol at Bastar plateau region of Chhattisgarh. No significant combined effect of fertilizer doses and row spacing in brown top millet on soil electrical conductivity was recorded in this study.

\section{Organic Carbon (OC)}

The data reveals that levels of fertilizer didn't create significant variation in the soil organic carbon content. Kang et al., (2005) reported that the application of chemical fertilizers had no effect on the soil organic carbon content, whereas, organic manures significantly increased the soil organic carbon. However, the results are not in accordance with the findings of Deekshitha et al., (2017); who find out that the fertilizer doses had significant effect on OC content in soil. 
The soil organic carbon content as influenced by fertilizer levels are ranged from 0.54 to $0.55 \%$ in the Entisol under study. The range of OC content was in accordance with the several workers. Nearly $50.4 \%$ soil samples of Dabhra block of Janjgir-Champa district with Entisols were reported medium in organic carbon content (Joshi,S. 2012). Similar results were reported in case of soils of Amritsar by Sharma et al., 2008. The soils of Sakti block (Entisols) are low to medium in organic carbon status and ranged from 0.21 to $0.68 \%$ with a mean value of $0.51 \%$ (Wany, 2012). The data clearly showed that row spacing of brown top millet, in an Entisol at Bastar plateau region of Chhatisgarh, had no significant effect on soil organic carbon. The interaction effect of levels of fertilizers with row spacing on soil organic carbon content is found significant but their simple effects are non significant hence it has no importance.

Table.1 Initial soil properties and nutrient status of experimental soil

\begin{tabular}{|c|c|c|c|}
\hline Soil properties & $\begin{array}{l}\text { Initial } \\
\text { status }\end{array}$ & Rating & Method \\
\hline pH & 5.86 & Slightly acidic & $\mathrm{pH}$ meter \\
\hline $\mathrm{EC}\left(\mathrm{dS} \mathrm{m}^{-1}\right)$ & 0.10 & Normal & EC meter \\
\hline $\mathrm{OC}(\%)$ & 0.55 & Medium & Walkley and Black (1934) \\
\hline $\mathbf{N}\left(\mathbf{k g ~ h a}^{-1}\right)$ & 163.07 & Very low & Subbiah and Asija, 1956. \\
\hline $\mathbf{P}\left(\mathrm{kg} \mathrm{ha}^{-1}\right)$ & 10.75 & Medium & Olsen et al. (1954) and Watnabe and Olsen (1965) \\
\hline K $\left(\mathbf{k g ~ h a}^{-1}\right)$ & 204 & Medium & Muhr et al. (1965) using flame photometer \\
\hline $\operatorname{Mn}\left(\mathrm{mg} \mathrm{kg}^{-1}\right)$ & 24.21 & Sufficient & Lindsay and Norvell (1978) using AAS \\
\hline Fe $\left(\mathrm{mg} \mathrm{kg}^{-1}\right)$ & 11.15 & Sufficient & Lindsay and Norvell (1978) using AAS \\
\hline $\mathrm{Zn}\left(\mathrm{mg} \mathrm{kg}^{-1}\right)$ & 1.2 & Sufficient & Lindsay and Norvell (1978) using AAS \\
\hline $\mathrm{Cu}\left(\mathrm{mg} \mathrm{kg}^{-1}\right)$ & 1.58 & Sufficient & Lindsay and Norvell (1978) using AAS \\
\hline
\end{tabular}

Table.2 Effect of levels of fertilizers and row spacing on soil parameters of brown top millet in Entisols of Bastar plateau

\begin{tabular}{|c|c|c|c|c|c|c|c|c|c|c|}
\hline \multirow[t]{2}{*}{$\begin{array}{l}\text { S. } \\
\text { No. }\end{array}$} & \multirow[t]{2}{*}{$\begin{array}{c}\text { Soil } \\
\text { properties }\end{array}$} & \multicolumn{3}{|c|}{$\begin{array}{c}\text { Fertilizer levels ( } \% \text { of } \\
\text { RDF) }\end{array}$} & \multirow[t]{2}{*}{$\begin{array}{c}\text { CD } \\
(P=0.05)\end{array}$} & \multicolumn{4}{|c|}{ Row spacing (cm) } & \multirow[t]{2}{*}{$\begin{array}{c}\text { CD } \\
(P=0.05)\end{array}$} \\
\hline & & 75 & 100 & 125 & & 22.5 & 30 & 45 & 60 & \\
\hline 1. & $\mathrm{pH}$ & 5.5 & 5.6 & 5.6 & NS & 5.4 & 5.6 & 5.6 & 5.6 & NS \\
\hline 2. & $\mathrm{EC}(\mathrm{dS} / \mathrm{m})$ & 0.07 & 0.08 & 0.09 & NS & 0.08 & 0.07 & 0.08 & 0.09 & NS \\
\hline 3. & $\mathrm{OC}(\%)$ & 0.54 & 0.54 & 0.55 & NS & 0.57 & 0.53 & 0.56 & 0.53 & NS \\
\hline 4. & $\mathrm{~N}\left(\mathrm{~kg} \mathrm{ha}^{-1}\right)$ & 178 & 217 & 255 & 22.5 & 205 & 212 & 218 & 233 & 12.6 \\
\hline 5. & $\mathrm{P}\left(\mathrm{kg} \mathrm{ha}^{-1}\right)$ & 6.2 & 8.5 & 10.8 & 1.0 & 7.6 & 8.4 & 8.8 & 9.3 & 0.7 \\
\hline 6. & $\mathrm{~K}\left(\mathrm{~kg} \mathrm{ha}^{-1}\right)$ & 181 & 174 & 178 & NS & 164 & 165 & 185 & 198 & 20.3 \\
\hline 7. & Mn (ppm) & 16.5 & 18.0 & 14.5 & NS & 16.7 & 14.1 & 16.6 & 18.0 & NS \\
\hline 8. & $\mathrm{Zn}(\mathrm{ppm})$ & 0.54 & 0.59 & 0.57 & NS & 0.47 & 0.63 & 0.64 & 0.54 & NS \\
\hline 9. & $\mathrm{Fe}(\mathrm{ppm})$ & 25.3 & 30.9 & 35.8 & 4.6 & 25.9 & 27.4 & 33.2 & 36.3 & NS \\
\hline 10. & $\mathrm{Cu}(\mathrm{ppm})$ & 0.75 & 0.78 & 1.46 & NS & 1.28 & 0.77 & 0.89 & 1.06 & NS \\
\hline
\end{tabular}

$\mathrm{CD}=$ Critical difference, $\mathrm{P}=$ Probability level of significance, NS=Not significant, $\mathrm{RDF}=\mathrm{Recommended}$ dose of fertilizer, cm=centimeter 
Fig.1
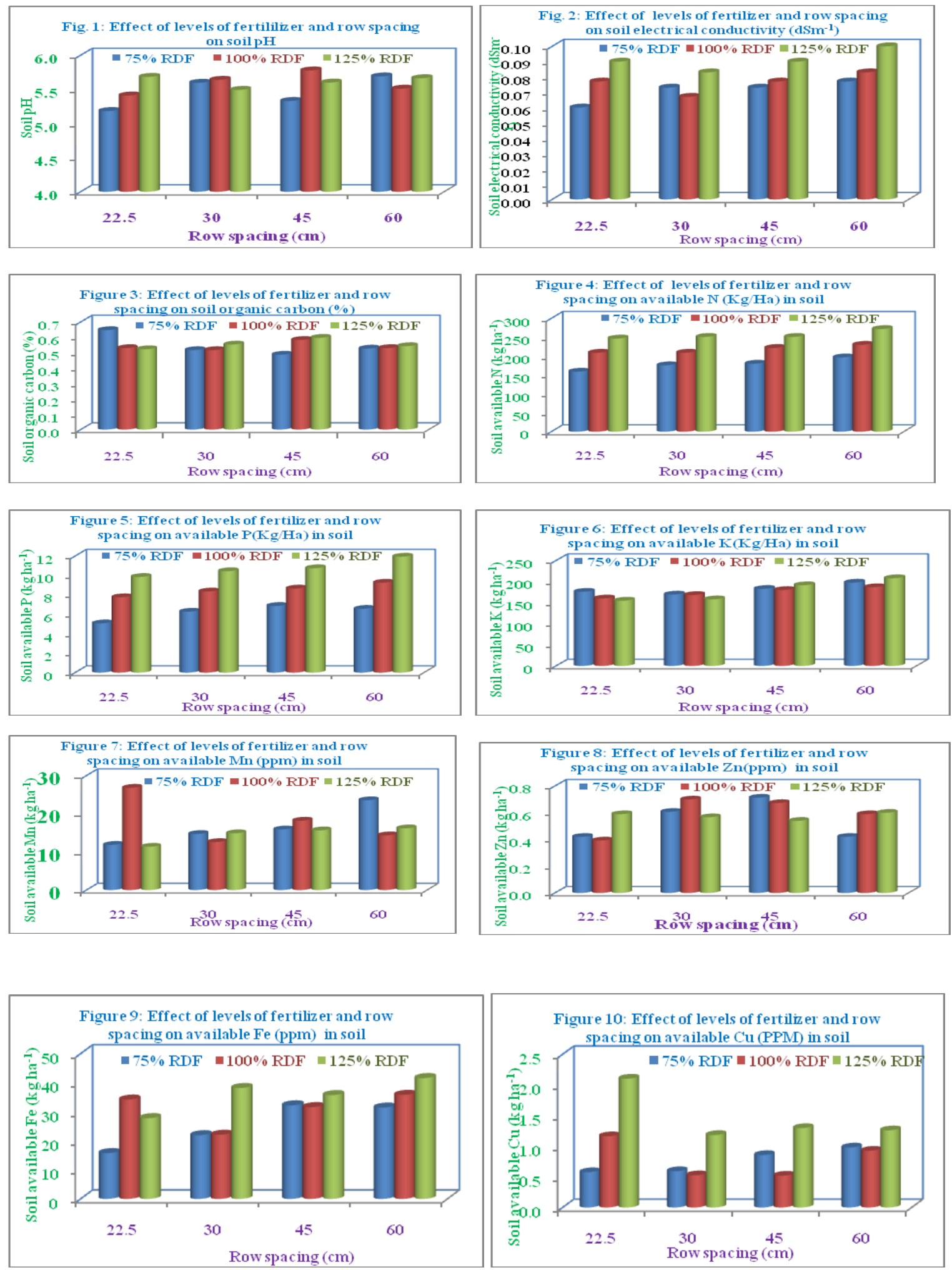


\section{Available $\mathbf{N}$ in soil}

The results reveal that the treatment $125 \%$ recommended dose of fertilizer had the highest available $\mathrm{N}\left(255 \mathrm{~kg} \mathrm{ha}^{-1}\right)$ in soil which was significantly higher than 75 and $100 \%$ recommended dose of fertilizer. The available $\mathrm{N}$ in soil increased significantly with each successive level of fertilizer. This was in accordance with the results obtained by Deekshitha et al., (2017) who reported $229 \mathrm{~kg}$ ha- ${ }^{1}$ highest and $163 \mathrm{~kg} \mathrm{ha}^{-1}$ lowest available $\mathrm{N}$ in soil in case of Bt Cotton. Similarly findings were also reported by Gogoi et al., (2010) in the case of soils of Jorhat. Wany (2012) reported the available $\mathrm{N}$ in Entisols ranging between 100 to $364 \mathrm{~kg} \mathrm{ha}^{-1}$.

The results reveal that the row spacing of 60 $\mathrm{cm}$ had the highest $\left(233 \mathrm{~kg} \mathrm{ha}^{-1}\right)$ available $\mathrm{N}$ in soil which was significantly higher than 45 , 30 and $22.5 \mathrm{~cm}$ row spacing. The row spacing of $45 \mathrm{~cm}$ had significantly higher available $\mathrm{N}$ in soil than the $22.5 \mathrm{~cm}$ row spacing. The available $\mathrm{N}$ showed a general increasing trend with the increase in row spacing. Deekshitha et al., (2017), Gogoi et al., (2010) and Wany (2012) were also reported similarly. No significant combined effect of fertilizer doses and row spacing in brown top millet on soil available $\mathrm{N}$ was recorded in this study.

\section{Available $\mathbf{P}$ in soil}

The results reveal that the treatment $125 \%$ of recommended dose of fertilizer had the highest $\left(10.8 \mathrm{~kg} \mathrm{ha}^{-1}\right)$ available $\mathrm{P}$ in soil which was significantly higher than the 75 and $100 \%$ of recommended dose of fertilizer. The available $\mathrm{P}$ in soil was increased significantly with each successive level of fertilizer. These results are in accordance with the findings of Reddy et al., (2006). The available $\mathrm{P}$ content increased with increase in fertilizer application (Deekshitha et al., 2017). Nirawar et al., (2009) reported the available phosphorous in the soils of Ahmedpur which was $16.15 \mathrm{~kg} \mathrm{ha}^{-1}$. Gorgoi et al., 2010 also reported available $\mathrm{P}$ as $12.1 \mathrm{~kg} \mathrm{ha}^{-1}$. Wany (2012) reported the available P in Entisols which was varying between 17.24 to $38.85 \mathrm{~kg}$ $\mathrm{ha}^{-1}$. The results reveal that the row spacing of $60 \mathrm{~cm}$. had the highest available P $\left(9.3 \mathrm{~kg} \mathrm{ha}{ }^{-}\right.$ ${ }^{1}$ ) in soil which was significantly higher than 30 and $22.5 \mathrm{~cm}$ row spacing and on par with $45 \mathrm{~cm}$ row spacing. The available $\mathrm{P}$ in soil was found at par with 45 and $30 \mathrm{~cm}$ row spacing and both were significantly higher than $22.5 \mathrm{~cm}$ row spacing. Reddy et al., (2006), Deekshitha et al., (2017), Nirawar et al., (2009), Gogoi et al., (2010) and Wany (2012) also reported similarly. No significant combined effect of fertilizer doses and row spacing in brown top millet on soil available $\mathrm{P}$ was recorded in this study.

\section{Available K in soil}

The result reveals that the effect of levels of fertilizer on available $\mathrm{K}$ in soil was found non-significant. It was ranging from 174 to $181 \mathrm{~kg} \mathrm{ha}^{-1}$. Sharma et al., (2006) reported that the available $\mathrm{K}$ ranged from 135 to 350 $\mathrm{kg} \mathrm{ha}^{-1}$ in soils of Molasar series (Typic Torripsaments) of Jaisalmer district of Rajasthan. Wany (2012) reported the available $\mathrm{K}$ in Entisols which was ranging between 90 to $264 \mathrm{~kg} \mathrm{ha}^{-1}$. The result reveals that the row spacing of $60 \mathrm{~cm}$ was recorded the highest available $\mathrm{K}$ in soil which was significantly higher than 30 and $22.5 \mathrm{~cm}$ row spacing and statistically at par with $45 \mathrm{~cm}$ row spacing of brown top millet. The available $\mathrm{K}$ in soil was found significantly higher under the row spacing of $45 \mathrm{~cm}$ as compared to $22.5 \mathrm{~cm}$ row spacing and statistically at par with 30 and $60 \mathrm{~cm}$ row spacing of brown top millet. No significant combined effect of fertilizer doses and row spacing in brown top millet on soil available $\mathrm{K}$ was recorded in this study. 


\section{Available Mn in soil}

The result reveals that the effect of fertilizer levels on the available $\mathrm{Mn}$ (ppm) in soil was found non significant. The range of available Mn (ppm) in soil was between 14.5 to 18.0 ppm. Kumar et al (2009) reported that available Mn range between 26.2 to $180.0 \mathrm{mg}$ $\mathrm{kg}^{-1}$. Singh et al., (2009) reported 3.2 to 8.5 $\mathrm{mg} \mathrm{kg}^{-1}$ of Mn from Ghazipur, UP. Wany (2012) reported the available $\mathrm{Mn}$ in soil in the range of 37.7 to $31.7 \mathrm{mg} \mathrm{kg}^{-1}$.

The result reveals that the effect of row spacing on the available Mn (ppm) in soil was also found non significant. No significant combined effect of fertilizer doses and row spacing in brown top millet on soil available Mn was recorded in this study.

\section{Available $\mathrm{Zn}$ in soil}

The results reveal that the effect of levels of fertilizer on the available $\mathrm{Zn}$ (ppm) in soil was found non significant. The available $\mathrm{Zn}$ in soil due to levels of fertilizer was ranging from 0.54 to $0.59 \mathrm{ppm}$ and the $\mathrm{Zn}$ deficiency was not found in this study. This was in accordance with the finding that the application of fertilizer had no significant effect on Zn content in soil (Deekshitha et al., 2017).

Several workers reported the $\mathrm{Zn}$ availability between 0.1 to $1.7 \mathrm{mg} \mathrm{kg}^{-1}$ in the soils of Nagpur, 0.32 to $1.40 \mathrm{mg} \mathrm{kg}^{-1}$ in the soils of Fatehgarh Sahib, Punjab, and $0.38 \mathrm{ppm}$ in the soils of Rajgarh, MP (Sharma et al., 2003 and Sharma et al., 2001). Wany (2012) reported the available $\mathrm{Zn}$ in Entisols between 0.6 to 2.8 $\mathrm{mg} \mathrm{kg}{ }^{-1}$. The result reveals that the effect of row spacing on the available $\mathrm{Zn}(\mathrm{ppm})$ in soil was also found non significant. No significant combined effect of fertilizer doses and row spacing in brown top millet on soil available $\mathrm{Zn}$ was recorded in this study.

\section{Available Fe in soil}

The results reveal that the treatment $125 \%$ of recommended dose of fertilizer had the highest (41.6 ppm) available $\mathrm{Fe}$ in soil which was significantly higher than the $75 \%$ and $100 \%$ of recommended dose of fertilizer. The available $\mathrm{Fe}$ in soil was increased significantly with each successive level of fertilizer. This might be either due to the acidifying effect during the nitrification of urea or through replacement of $\mathrm{Fe}^{2+}$ from exchangeable site on clay by the $\mathrm{NH}_{4}{ }^{+}$ion formed after its hydrolysis; this was in agreement with findings of Tarafdar et al., 2011. The result reveals that the effect of row spacing on the available $\mathrm{Fe}$ (ppm) in soil was also found non significant. No significant combined effect of fertilizer doses and row spacing in brown top millet on soil available Fe was recorded in this study.

\section{Available $\mathrm{Cu}$ in soil}

The results reveal that the fertilizer doses and spacing had no significant effect on availability of $\mathrm{Cu}$ in soil. The results were in accordance with the findings of Deekshitha $e t$ al., (2017) and Singh et al., (2009). Wany (2012) reported the availability of $\mathrm{Cu}$ in Entisols to the tune of $1.2 \mathrm{mg} \mathrm{kg}^{-1}$. The result reveals that the effect of row spacing had no significant effect on availability of $\mathrm{Cu}$ in soil. No significant combined effect of fertilizer doses and row spacing in brown top millet on soil available $\mathrm{Cu}$ was recorded in this study.

\section{References}

Deekshitha D. K. D., Ravindra Babu P., and Madhuvani P. 2017. Effect of fertilizer levels and sulphur on soil properties in clay soil. Plant Archives Vol. 17 No. 2, 2017 pp 846-850.

Fuller, D.Q. (2014). Brown Top Millet: Origins and Development, Chapter, the 
Archaeological Record (pp.1021-024).

Gogoi,B., Barua, N.G. and Baruah, T.C. (2010). Effect of integrated nutrient management on growth, yield of crops and availability of nutrients in inceptisol under rainfed rice (Oryza sativa)- niger (Guizotia abyssinica) sequence of Assam. Indian Journal of Agricultural Sciences, 80: 56-6

Jena, D., Mohanty, B. and Nayak, S.C. (2008). Distribution of available sulfur, zinc, copper, iron, manganese and boron in deltaic alluvial soil (Ustipsamment) in relation to certain soil properties. Environment and Ecology.2007; 25 (4): 730-733.

Jamal, A., Moon, Y. S, Abdin, M. Z. (2010). Sulphur -a general overview and interaction with nitrogen. Australian Journal of Crop Science. 4(7): 523529.

Joshi. S., (2012). Evaluation of soil fertility status in soils of Dabhara block, under Janjgir Dist. of Chhattisgarh. MSc. (Ag.) Thesis.

Kang, G.S., Beri,V., Sindhu, B.S., Rupela, O.P. (2005). A new index to assess soil quality and Sustainability of wheatbased cropping system. Biology and fertility of soil 41(6): 389-398.

Kimata,M., E.G. Ashoka and A. Seetaram.(2000). Domestication, cultivation and utilization of two small millets, Brachiaria ramosa and Setaria glauca (Poaceae) in South India. Economic Botany 54 (2): 217-27.

Kumar R., Sarkar, A. S., Singh, K. P., Agarwal, B. K. and Karmakar, S. (2009). Appraisal of available nutrients status in Santhal Paraganas region of Jharkhand. J. Indian Soc. Soil Sci. 57(3): 366-369.

Lindsay, W.L., Norvell, W.A. (1978). Development of a DTPA soil test for zinc, iron, manganese, and copper. Soil Science Society of America Journal
42: 421-428

Muhr, G.R., Datta, N.P., Sankarasubramoney, H., Dever, F., Laley V.K. and Donahue R.L. (1965). Critical test value for available N,P and $\mathrm{K}$ in different soils. Soil Testing in India. 2nd edn. U.S Agency for International Development, New Delhi: 120.

Nirawar, G. V., Mali, C. V., and Waghmare, M. S. (2009). Physico chemical characteristics and status of available $\mathrm{N}, \mathrm{P}$ and $\mathrm{K}$ in soils from Ahmedpur tahsil of Latur district. An Asian J. Soil Sci. 4(1): 130-134.

Olsen SR, Cole CV, Watanabe FS and Dean LA (1954). Estimation of available phosphorus in soils by extraction with sodium bicarbonate. USDA Circ. No. 939, Washington.

Parameswar, M., V. Shanthaian, M. Singa Rao, A. Prasado Rao, and P. Nageswara Rao. (1989). Effectof longterm fertilization under intensive cropping on some soil physical properties and rice yields. Andhra Agricultural Journal36:152-156.

Ratre, S.R. (2014). Zones namely Chhattisgarh Plain, Northern Hills and Bastar Plateau, PhD thesis.

Reddy, M.D, Rama Lakshmi,S., Rao,C.N., Rao, K.V., Sitaramaya, M., Padmaja, G. and Raja Lakshmi, T. (2006). Effect of long term integrated nutrient supply on soil chemical properties, nutrient uptake and yield of rice. Indian Journal of Fertilizers 2: 25-28.

Sarkar, S., and S.R. Singh. (1997). Integrated nutrient management in relation to soil fertility and yield sustainability under dryland farming. Indian Journal of Agricultural Sciences, 67:431-433.

Sharma, Y.M and Gupta, G. P. (2001). Distribution of total and available micronutrients in profiles of different soils of Madhya Pradesh. Annals of Agricultural Research. 22(1): 125. 
Sharma, P.P., Meghsingh and Sharma, J.P. (2003). Correlation studies on micronutrients vis-à-vis soil properties in some soils of Nagpur district in Semi-arid region of Rajasthan. Journal of the Indian Society of Soil Science. 51(4): 522-527.

Sharma, B.K., Singh, N. and Kumar, H. (2006). Sandy soils of Jaisalmer district, their morphogenesis and evaluation for sustainable land use. Annals of Arid zone. 45:139-149.

Sharma, P.K., Sood, A., Setia, R.K., Tur, N.S., Mehra, D. and Singh, H. (2008) Mapping of macronutrients in soils of Amritsar district (Punjab) - A GIS approach, Journal Of Indian Society of Soil Science, Vol. 56, No. 1,pp 34-41.

Singh, V.S., Agrawal, H.P. and Prasad, S. (2009). Distribution of DTPAextractable micro nutrients in the soils of district Ghazipur, Uttar Pradesh. $J$. Indian Soc. Soil Sci. 57(3): 370-372.

Subbiah BV and Asija GL. 1956. A raped processor of determination of available nitrogen in nitrogen in soil. Curr. Sci. 25: 259-260.

Tarafdar, J.C. and Kumar, P. (2011). Effect of urea on availability of micronutrients in arid soil. J. Indian Society of Soil Sci. 59(2): 148-157.

USDA-NRCS. Archived from the original on May 9, 2006. Retrieved 2006-05-14.

Walkley, A. and Black, I.A. (1934). An examination of the Degtjareff method for determining soil organic matter and a proposed modification of the chromic acid titration method. Soil Sci., 37: 2938.

Wany, A., (2012). Assessment of soil fertility status of noticeable red and yellow soils of Sakti block of Janjgir-Champa Dist. Of Chhattisgarh. MSc. (Ag.) Thesis.

Watanabe, F.S. and Olsen, S.R. (1965) Test of an Ascorbic Acid Method for Determining Phosphorus in Water and $\mathrm{NaHCO}_{3}$ Extracts from the Soil. Soil Science Society of America Journal, 29, 677-678.

\section{How to cite this article:}

Danish Ahmed Siddiqui, G. K. Sharma, T. Chandrakar, A. K. Thakur, and Pradhan, A. 2020. Effect of Differential Levels of Fertilizer and Row Spacing of Brown Top Millet [Brachiaria ramosa (L.)] on Soil Physicochemical Properties of Entisol of Bastar Plateau Zone of Chhattisgarh. Int.J.Curr.Microbiol.App.Sci. 9(09): 989-998. doi: https://doi.org/10.20546/ijcmas.2020.909.123 